\title{
シャント機能テストについて
}

バルブ内髄液圧測定，RI study, Infusion test の意義

中田 義隆・能勢 忠男・伴野 悠士・牧豊

\section{Evaluation Method of Shunt Function}

Combination of CSF Pressure Measurement, Radioisotope Study, and Infusion Test

\author{
Yoshitaka Nakada, Tadao Nose, Yuji Tomono and Yutaka Maki \\ Department of Neurological Surgery, Institute of Clinical Medicine, University of Tsukuba, Ibaraki
}

\begin{abstract}
Shunt function tests were carried out 52 times in 32 cases of suspected malfunction of ventriculoperitoneal or ventriculoatrial shunt. Shunt function tests consisted of radioisotope (RI) study (flow study and shuntgraphy), CSF pressure measurement, and infusion test. The first was performed in all cases, the second in half, and the last in eight.

In the majority of the cases it was not enough to evaluate the shunt function by RI study alone as about $45 \%$ of the 21 cases which showed an abnormal flow pattern and abnormal shuntgraphy were found either by surgery or infusion test to actually have patent shunt systems. Such cases were regarded as false positive. All of the three cases which showed abnormal delayed flow pattern and high CSF pressure (above $150 \mathrm{mmH}_{2} \mathrm{O}$ ) were found by surgery to have shunt blockage. In addition to RI study, measurement of CSF pressure in the valve was necessary to correctly evaluate shunt functioning. Nine cases which showed delayed flow pattern and low or normal CSF pressure were classified by surgery and/or infusion test into two groups, i.e. the shunt-obstructed group ( 3 cases), and the shunt-patent group (6 cases). As the opening pressure of the shunt system was revealed by the infusion test, this test was very important in evaluating shunt patency for these cases.
\end{abstract}

Key words: hydrocephalus, CSF shunt, shunt malfunction, shunt function test, infusion test

\section{I はじめに}

水頭症に対するシャント術後に，再び頭蓋内圧え進症状 が出現する，疾杂などの症状が改善されない，掂大した脳 室が縮小しないなどシャント機能不良を疑わせる症例に 遭遇することがある。その場合，真にシャントの機能が不 良であるのか，そらであ机ばどの部位であるのかをみきわ めることは，不必要な手術をさけるためにも，必要な再建 術を行う際の手術時間の短縮のためにも，きわめて大切な ことである。今までに報告されているシャント機能テスト には数種類の方法があるが，我々は徒来主として radioiso- tope $(\mathbf{R I})$ によるシャント機能テストを行ってきた. 今回 それらのデータを分析し報告するととむに，シャント機能 検査の進め方についても考察する.

\section{II 対象および方法}

\section{1. 対象}

1977年10月より1982年 7 月までに，水頭症に対する髄液 シャント術後に機能不良を疑わせた小児18名，成人14名の 計32名を対象とした. RI シャント機能テストの回数は小 呪31回，成人21回の計52回である、検查時に施行されてい たシャント術式は ventriculo-peritoneal shunt (V-Pシャ

\section{筑波大学檤神経外科}

Address reprint requests to: Y. Nakada, M. D., Department of Neurological Surgery, Institute of Clinical Medicine, University of Tsukuba, Tennodai, Sakura-mura, Niihari-gun, Ibaraki 305.

受稿

1982年 9 月 14 日
受理 1983年 5 月 12 日 
ント)46例, ventriculo-atrial shunt（V-A シャント) 5 例, cyst-peritoneal shunt（C-P シャント）1例である。用いら れていたバルブは過半数が Pudenz flushing valve であり， 残りは Mishler double lumen flushing valve 抢よび Mishler double chamber flushing valve であった。

\section{2. $\mathbf{R I}$ シャント機能テスト}

この検查はバルブ内㵦液の flow study と shuntgraphyよ り成る。

Flow study : 患者を横卧位にし,シャントバルブ上の 頭皮の消毒を行 5。25G針にて経皮的にシャントバルブ脑 室側を穿刺し, ${ }^{89 \mathrm{~m}} \mathrm{TcO}_{4}{ }^{-} 1 \mathrm{mCi}(0.3 \mathrm{ml})$ 速やかに注入市 る、コリメーターを有するガンマシンチレーションカメラ をバルブ上 $5 \mathrm{~cm}$ に設置し，RI 注入時より10秒単位で10分 間の RI カウントt得, data analyserによりバルブ内の RI クリアランス曲線求める。

Shuntgraphy: Flow study 終了後ただちに脳室拉よで胸 部・腹部の撮影を行ら。撮影後もバルブ内に RI がかなり 残存しているときは，RI の脳室内逆流と末梢側チューブ および腹腔内人の拉散の程度を知る目的で，頭皮上よりバ ルブをパンピングして再度頭部・胸部・腹部を撮影寸る。

\section{3. 髄液圧の測定}

約半数の症例で，バルブの脳室側穿刺あるいは腰椎穿刺 に上り娟液圧の測定索行った。

\section{Infusion test}

Flow studyと shuntgraphyにてシャント機能不良が疑わ れているにもかかわらず髄液圧が正常ないし低圧の場合 に,シャントバルブの作動開始圧を知る目的で infusion test を施行した。本テストは Katzman and Hussey”の方法に より，患者を側卧位にし20G 針で腰椎穿刺を行う。初压索 みたあと，Harvard infusion pumpにより生理的食塩水を $0.76 \mathrm{ml} / \mathrm{min}$ で持続注入し，plateauに達する髄液)王(最高 圧)を得ここれをシャントシステムの作動開始圧とみなし た. 最高圧が成人で汢150 $\mathrm{mmH}_{2} \mathrm{O}$ 以上，小児で注諸家の 報告1,5,6,13,14) 参考にして $110 \mathrm{mmH}_{2} \mathrm{O}$ 以上を異常所見と した.

\section{III 結 果}

\section{Shuntgraphy の結果}

末梢側シャント機能不良，中枢側シャント機能不良，シ ヤント開存の 3 群に分類しえた，末梢側機能不良上は，バ

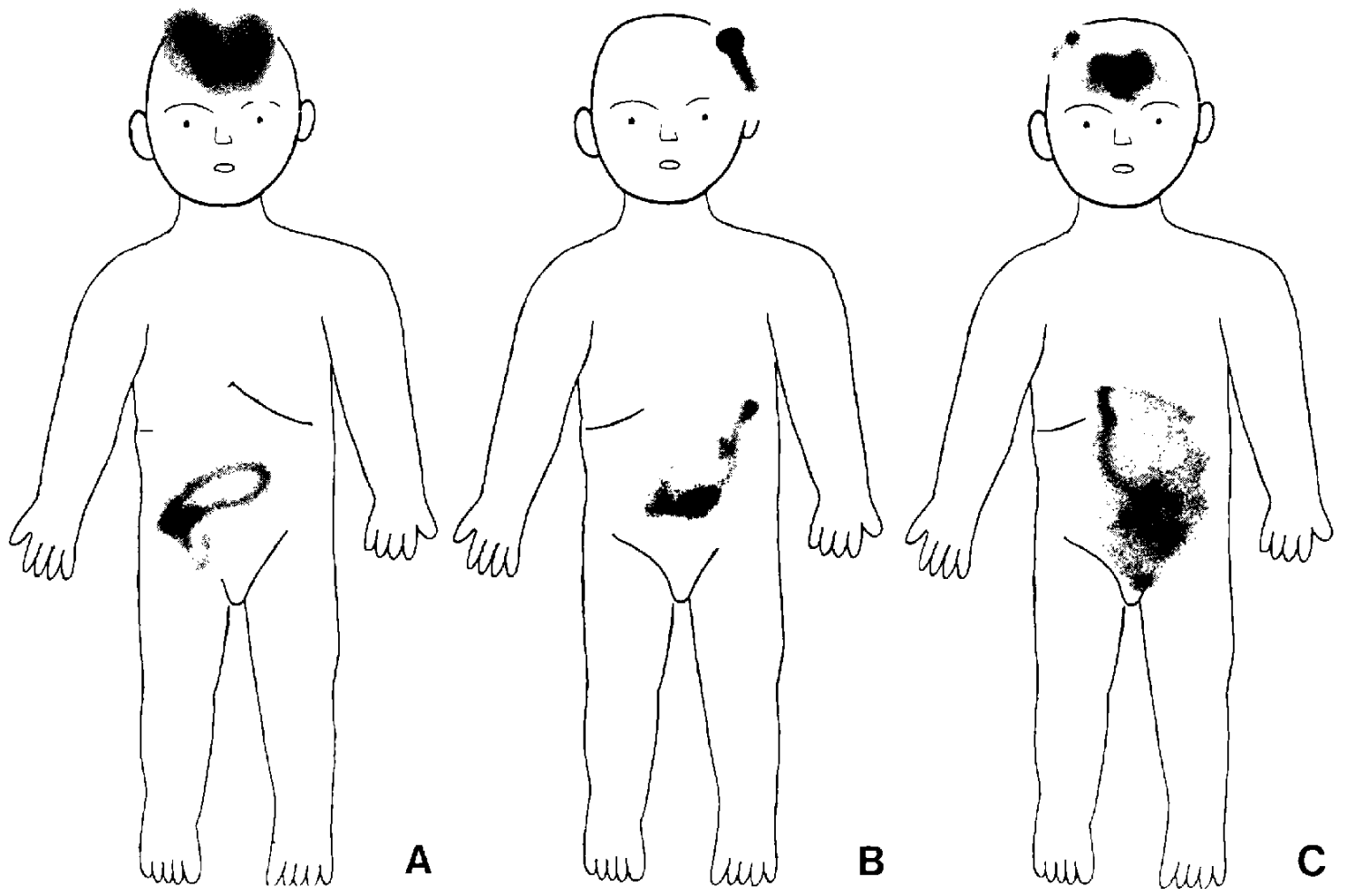

Fig. 1 Three types of shuntgram. A: Distal tube malfunction. Ventricular reflux $(+)$ and lack of RI spread into the abdominal cavity after valve pumping. B: Ventricular tube malfunction. No ventricular reflux of RI after valve pumping. C: Shunt functioning. Ventricular reflux $(+)$, diffuse RI spread into the abdominal cavity after valve pumping. 
ルブ内に注入された RI が末梢側一拉散せず，さらにバル ブのパンピング後に RI が脳室へ逆流するが末梢側チュー ブ全体には及ばず中断してみえるものであり，V-P shunt の場合はパンピング後 RI が腹腔内に十分拡散しないもの (Fig. 1A) 索言う。中枢側機能不良とは，バルブ内の RIが パンピンダ後に末梢側へと移動するが脳室内一逆流しない もの(Fig. 1B)，西るい朔流してす脳室全体に十分拡散し ないものを言 5 、シャント開存とは，バルブ内の RI が脑 室招上び腹腔内に十分抬散するもの(Fig. 1C) である。 Shuntgraphy の結果は，末梢側機能不良 24 例 $(46 \%)$ ，中枢 側機能不良10例(19\%)，シャント開存18例(35\%)であった。

\section{Flow study の結果}

シャント機能時の流量としては，後述するごとく諸家の 報告からみても $\mathrm{T}_{1 / 2}$ が 5 分以内(我々の実験結果では流量 $0.07 \mathrm{~m} / \mathrm{min}$ 以上)であれ汪淁十分と考えられたので， flow study の結果を以下の 3 型に分けた。すなるち，10分 間まったく flow のない no flow pattern (Fig. 2A), flow は あるが $\Gamma_{1 / 2}$ が 5 分以上の delayed flow pattern (Fig. 2B)， 执よび 5 分以内の rapid flow pattern (Fig. 2C)である。 No flow pattern 21 例 $(40 \%)$, delayed flow patternは15例 $(29 \%)$, rapid flow pattern は16例(31\%)であった。

\section{3. 各 flow pattern を示す症例の分析}

No flow pattern (21例, Table 1)

<Shuntgram の所見とその結果>：Flow study で no flow pattern 走す21例の shuntgram の彭断注，中枢側機能不 良 7 例, 未梢側機能不良 13 例, シャント開存 1 例であっ た。機能不良上された20例中手術により機能不良が確婄さ れをものは11例(55\%)で，他の9例(45\%)はいずれも手術 や infusion test などからシャント昷存しているむのと判 䉼された。すなおち $45 \%$ は false positive で, flow study と shuntgramの結果のみで柱十分な診断が下せないと言える。 く䯣液压とシャント機能〉：21例中15例に䯣液圧の測定が なされ，その結果高圧群，低压ないし正常圧群の二群に分 けえた。高压群 5 例 (〈症例 $1 \sim 5\rangle$ ) の髄液圧は170 360 $\mathrm{mmH}_{2} \mathrm{O}$ の間にあり，その shuntgram は全例機能不良を示 し，手術の結果も全例未梢側開塞齐認女た。低压ないL正 常圧群10例(〈症例 $6 \sim 15\rangle$ )で注正常圧が 1 例で，9 例は 0 $\sim 95 \mathrm{mmH}_{2} \mathrm{O}$ と低圧であり，その shuntgram は10例中 9 例が機能不良を示した。この9例中, 㖪液压測定不能の 1 例汇腷室管閉塞が，また2例に末梢側閉塞が証明された。 しかし他の 6 例は，手術や infusion test の結果から機能良 好上判断された，以上から，測定可能な正常压ないし注 圧で，かつ shuntgram で異常所見を呈する症例に注，infusion test を行わ枚代 false positive 鑑別できないことが 判った.

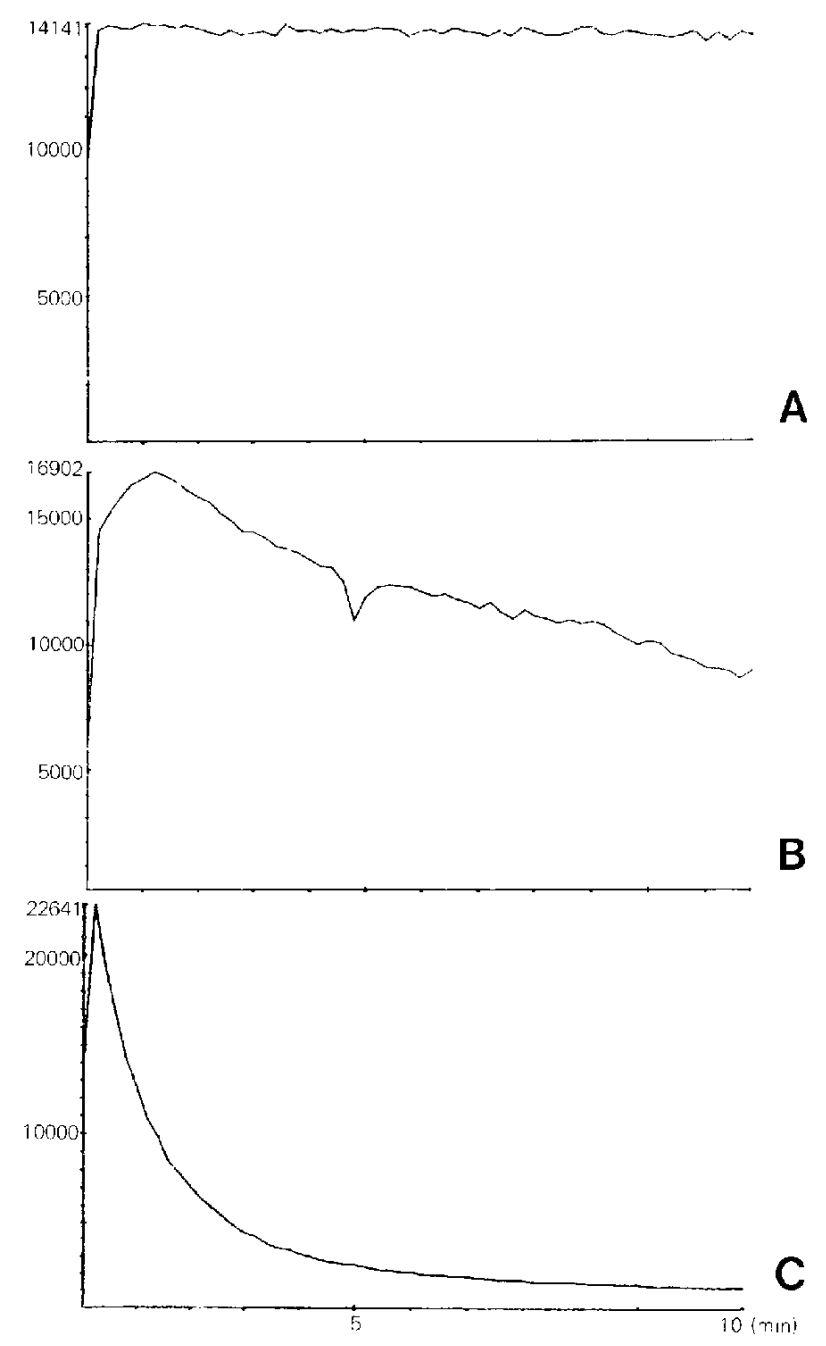

Fig. 2 Three types of RI-flow pattern. A: No flow pattern, lack of spontaneous clearance. B: Delayed flow pattcrn. Half time of clearance $\left(T_{1 / 2}\right)$ is over 10 minutes. C: Rapid flow pattern. Rapid clearance $T_{1 / 2}$ is 70 seconds.

Delayed flow pattern (15例, Table 2)

<Shuntgram の所見とその結果>：Shuntgram では，15例 中 3 例が中枢側機能不良，11例が末梢側機能不良，1例が シャント開存と診断された．機能不良とされた14例中 8 例 (57\%) はシャント閉塞が証明されたが，6例(43\%) は手術 や infusion test の結果から機能良好と判断された。すなわ ち，43\%が false positiveであり，flow study と shuntgram の結果のみではシャント機能を正確に診断し吝ないことが 判った。

く髄液压とシャント機能〉：15例中10例に髄液压の測定が なされ，その結果高圧群と低圧群に分けえた。高圧群 3 例 (く症例22 24〉)の shuntgramはいずれも末梢側機能不良と 
Table 1 Cases showing no flow pattern on RI-shunt flow study

\begin{tabular}{|c|c|c|c|c|c|c|c|c|}
\hline \multirow[b]{2}{*}{ Case } & \multirow[b]{2}{*}{ Age } & \multicolumn{3}{|c|}{ Shuntgram } & \multirow{2}{*}{$\begin{array}{l}\text { CSF } \\
\text { pressure } \\
\left(\mathrm{mm} \mathrm{H}_{2} \mathrm{O}\right)\end{array}$} & \multicolumn{2}{|c|}{ Infusion test } & \multirow[b]{2}{*}{ Remarks } \\
\hline & & $\begin{array}{l}\text { Distal } \\
\text { spread }\end{array}$ & VR & Diagnosis & & RP & MP & \\
\hline 1 & 63 & - & - & $V$-tube malf. & $200, \mathrm{~L}$ & & & OP, adh. of P-tube in the abd. cavity \\
\hline 2 & 1 & - & + & P-tube malf. & $180, \mathrm{~V}$ & & & OP, obstruction at the tip of P-tube \\
\hline 3 & 2 & $\ldots-$ & + & " & $170, \mathrm{~V}$ & & & OP, obstruction at the tip of P-tube \\
\hline 4 & 11 & \pm & + & " & $360, \mathrm{~V}$ & & & OP, dislocation of P-tube to the abd. wall \\
\hline 5 & 14 & + & + & " & $220, \mathrm{~V}$ & & & OP, CSF malabsorb. in the abd. cavity \\
\hline 6 & 3 & + & - & $V$-tube malf. & $0, \mathrm{~V}$ & & & OP, obstruction at the tip of $V$-tube \\
\hline 7 & 4 & \pm & - & " & $85, \mathrm{~V}$ & & & $\mathrm{OP}$, obstruction at the tip of A-tube \\
\hline 8 & 3 & - & + & P-tube malf. & $60, \mathrm{~V}$ & & & $\mathrm{OP}$, no obstruction \\
\hline 9 & 25 & + & + & " & $130, \mathrm{~L}$ & & & OP, no obstruction \\
\hline 10 & 51 & \pm & + & " & $95, \mathrm{~L}$ & 95 & 180 & OP, obstruction at the tip of $\mathbf{P}$-tube \\
\hline 11 & 53 & + & + & $"$ & $60, \mathrm{~L}$ & 60 & 140 & observ., symptoms unchanged \\
\hline 12 & 53 & + & + & $"$ & $80, \mathrm{~L}$ & 80 & 110 & observ., symptoms improved \\
\hline 13 & 56 & + & + & $"$ & $60, \mathrm{~L}$ & 60 & 120 & observ., symptoms unchanged \\
\hline 14 & 69 & \pm & + & $"$ & $80, \mathrm{~L}$ & & & observ., symptoms improved \\
\hline 15 & 56 & H & + & functioning & $50, \mathbf{L}$ & 50 & 90 & OP, no obstruction \\
\hline 16 & 1 & $+\frac{1}{1}$ & - & $V$-tube malf. & & & & $\mathrm{OP}$, no obstruction \\
\hline 17 & 5 & - & - & " & & & & OP, obstruction of A-tube \\
\hline 18 & 11 & + & - & $"$ & & & & OP, obstruction of A-tube \\
\hline 19 & 50 & + & - & " & & & & OP, no obstruction \\
\hline 20 & $6 \mathrm{mos}$ & - & + & A-tube malf. & & & & OP, obstruction of A-tube \\
\hline 21 & 51 & $=$ & + & P-tube malf. & & & & observ., symptoms improved \\
\hline
\end{tabular}

In Distal spread, - indicates no visualization of distal tube; \pm , visualization of distal tube; + , localization of $R I$ into abdominal cavity; + , cntire diffusion of $\mathrm{RI}$ into abdominal cavity. In VR, - indicates no ventricular reflux; +, ventricular reflux. V-tube malf. indicates ventricular tube malfunction; P-tube malf, peritoneal tube malfunction; A-tube malf., atrial tube malfunction; $V$, valve puncturc; $L$, lumber puncture; RP, resting pressure; MP, maximum pressure; OP, operation; observ., observation; abd., abdominal; adh., adhesion.

診断され，手術の結果でも全例に末梢側閉塞が認められた。 一方低圧ないし正常圧群 7 例の shuntgram では 6 例が機能 不良を示しこの6例中 2 例のみにシャント閉塞を認め, 他の 4 例は手術や infusion test の結果からシャント開存上 判断された。すなわちこの群でも, shuntgram で機能不良 の所見を呈する症例のらち true positive 䄪 $30 \%$ で, true positive と false positive $の$ 鑑別には infusion test が必要で あることが判明した。

Rapid flow pattern (16例, Table 3)

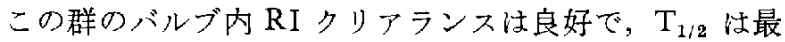
短 30 秒, 最艮 5 分, 平均 2 分 45 秒であった. Shuntgram で は RI の腹腔内拢散は良好であった。手術は1例に行われ たが閉塞は認めず，他の15例は機能良好と判断されて経過 を観察した。

\section{Shuntgraphy による閉塞部位診断}

Shuntgram 上の中枢側機能不良 (10例)
手術により10例中 8 例にシャント閉塞を認め, そのうち 3 例( 症例 $6,32,33$ ) が中枢側閉塞, 5 例( 症例 1,7 , $17,18,25\rangle)$ が梢側閉塞であった，バルブ内髅液圧は 4 例 (〈症例 1，6，7，25〉) で測定され，脳室管閉塞の 1 例は $0 \mathrm{mmH}_{2} \mathrm{O}$ と压測定不能でかっ波動も認めず，末梢側機能 不良のそれより極度に低い值を示した，以上ょり，中枢側 機能不良の診断には, shuntgram と併せてバルブ内䯣液圧 の測定が必要であることが明らがになった。

\section{Shuntgram 上の末梢側機能不良 (24例)}

手術により24例中11例に末梢側閉塞を認めた。閉塞の部 位はいずれも末梢側で，腹腔内 1 例(䯣液吸収不全)，末梢 管先端 8 例（末梢管の腹腔内痖着 2 例，末末梢管閉塞 5 例， 末梢管不完全閉塞の疑い 1 例), 腹壁 1 例 (腹腔管の腹壁内 冕脱)，䫫部 1 例(腹腔管の disconnection)であった，11例 中 9 例ではshuntgram 上の機能不良の部位と手術による閉 塞部位が一致していたが，2例では一致していなかった。 
Table 2 Cases showing delayed flow pattern on RI-shunt flow study

\begin{tabular}{|c|c|c|c|c|c|c|c|c|}
\hline \multirow[b]{2}{*}{ Case } & \multirow[b]{2}{*}{ Age } & \multicolumn{3}{|c|}{ Shuntgram } & \multirow{2}{*}{$\begin{array}{l}\mathrm{CSF} \\
\text { pressure } \\
\left(\mathrm{mm} \mathrm{H}_{2} \mathrm{O}\right)\end{array}$} & \multicolumn{2}{|c|}{ Infusion test } & \multirow[b]{2}{*}{ Remarks } \\
\hline & & $\begin{array}{l}\text { Distal } \\
\text { spread }\end{array}$ & VR & Diagnosis & & $\mathrm{RP}$ & MP & \\
\hline 22 & 3 & \pm & + & P-tube malf. & $250, \mathrm{~V}$ & & & OP, adh. of P-tube in the abd. cavity \\
\hline 23 & 5 & \pm & + & " & $170, \mathrm{~V}$ & & & OP, adh. of P-tube in the abd. cavity \\
\hline 24 & 5 & \pm & + & $"$ & $320, \mathrm{~V}$ & & & OP, obstruction at the tip of P-tube \\
\hline 25 & $11 \mathrm{mos}$ & + & - & V-tube malf. & $80, \mathrm{~V}$ & & & OP, obstruction at the tip of $\mathrm{P}$-tube \\
\hline 26 & 17 & + & + & P-tube malf. & $140, \mathrm{~L}$ & & & OP, no obstruction \\
\hline 27 & 17 & + & + & " & $110, \mathrm{~L}$ & & & OP, no obstruction \\
\hline 28 & 56 & + & + & " & $100, \mathrm{~L}$ & 100 & 200 & repeated tap \& valve pumping \\
\hline 29 & 63 & \pm & + & $"$ & $70, \mathrm{~L}$ & & & OP, no obstruction \\
\hline 30 & 76 & + & + & $" 1$ & $120, \mathrm{~L}$ & 120 & 140 & observ., symptoms improved \\
\hline 31 & 51 & H & + & functioning & $120, \mathrm{~L}$ & 120 & 130 & observ., symptoms improved \\
\hline 32 & 1 & \pm & - & V-tube malf. & & & & OP, obstruction of V-tube \\
\hline 33 & 1 & \pm & - & " & & & & OP, obstruction of V-tube \\
\hline 34 & 5 & + & + & P-tube malf. & & & & OP, disconnection of P-tube at the neck \\
\hline 35 & 25 & +- & + & \% & & & & OP, no obstruction \\
\hline 36 & 60 & + & + & $"$ & & & & observ., symptoms improved \\
\hline
\end{tabular}

Table 3 Cases showing normal flow pattern on RI-shunt flow study

\begin{tabular}{|c|c|c|c|c|c|c|c|}
\hline \multirow[b]{2}{*}{ Case } & \multirow[b]{2}{*}{ Age } & \multirow[b]{2}{*}{$\mathrm{T}_{1 / 2}$} & \multicolumn{3}{|c|}{ Shuntgram } & \multirow{2}{*}{$\begin{array}{l}\mathrm{CSF} \\
\text { pressure } \\
\left(\mathrm{mm} \mathrm{H} \mathrm{H}_{2} \mathrm{O}\right)\end{array}$} & \multirow[b]{2}{*}{ Remarks } \\
\hline & & & $\begin{array}{l}\text { Distal } \\
\text { spread }\end{array}$ & VR & Diagnosis & & \\
\hline 37 & 8 & $30^{\prime \prime}$ & + & & functioning & $50, \mathrm{~V}$ & observ., over drainage symptoms \\
\hline 38 & 9 & $1^{\prime}$ & H & & " & $60, \mathrm{~V}$ & observ., symptoms improved \\
\hline 39 & $5 \mathrm{mos}$ & $2^{\prime}$ & + & - & " & & observ., large ventricle collapsed \\
\hline 40 & $11 \mathrm{mos}$ & $1^{\prime} 40^{\prime \prime}$ & + & + & $"$ & & observ., slit ventricle \\
\hline 41 & 1 & $3^{\prime}$ & + & + & " & & observ., symptoms improved \\
\hline 42 & 1 & $3^{\prime} 20^{\prime \prime}$ & $H$ & - & $"$ & & observ., symptorns improved \\
\hline 43 & 1 & $3^{\prime}$ & + & + & $"$ & & OP, no obstruction \\
\hline 44 & 4 & $2^{\prime}$ & + & + & " & & observ., enlarged ventricle unchanged \\
\hline 45 & 6 & $3^{\prime} 40^{\prime \prime}$ & H & & $"$ & & observ., enlarged ventricle unchanged \\
\hline 46 & 7 & $3^{\prime}$ & H & + & $"$ & & observ., enlarged ventricle unchanged \\
\hline 47 & 8 & $4^{\prime}$ & $H$ & & $"$ & & observ., symptoms improved \\
\hline 48 & 9 & $3^{\prime}$ & H & & $"$ & & observ., cnlarged ventricle unchanged \\
\hline 49 & 9 & $1^{\prime} 10^{\prime \prime}$ & $H$ & - & $"$ & & observ, symptoms unchanged \\
\hline 50 & 50 & $5^{\prime}$ & $H$ & + & " & & obscrv., symptoms unchanged \\
\hline 51 & 56 & $4^{\prime} 40^{\prime \prime}$ & $H$ & & " & & observ., symptoms unchanged \\
\hline 52 & 76 & $3^{\prime}$ & $H$ & + & " & & observ., symptoms improved \\
\hline
\end{tabular}

その 2 例は，頸部機能不良とされた腹壁内逸脱例と腹腔管 先端部機能不良とされた顧部での disconnection 例である。 このよ5に, shuntgram で中枢側機能不良とされた場合 は，脳室管閉塞例は末梢管閉塞例よりむむしろ少なく，閉
塞部位に関する診断率任低かった，一方 shuntgramで末梢 側機能不良とされた場合は，脳室管閉塞例はなく閉塞部位 の診断率注高加った。 


\section{IV 考察}

\section{Flow study}

Flow study はシャントチューブの髄液流量を客観的に 知る上で重要である。我々はHayden $6^{42}$ の診断基準に基 ゔき, $\mathrm{RI}$ クリアランスから $\mathrm{T}_{1 / 2}$ を求め, 5 分以内は rapid flow pattern $と L ， 5$ 分以上老 delayed flow $\llcorner$ no flow patternに分けた， $T_{1 / 2}$ の流量は我々の実験によると 0.07 $\mathrm{m} l / \mathrm{min}$ に相当し(Fig. 3), 前田ら”の $0.15 \mathrm{ml} / \mathrm{min}$ 上り 低值である。この相違は，バルブ内人の RI 注入量の相違 によるものと推定される。才なわち, 前田らの淮入量が $0.15 \mathrm{ml}$ であるのに対し我々のそれは $0.3 \mathrm{ml}$ と量が多く, このため注入時のバルブ内の寒量增加が大きくなり，注入 後の RI クリアランスに影響したのではないかと考えられ

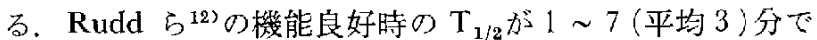
あったこと，大矢 $5^{11} の$ 機能良好時 $の$ 流量が $0.03 \sim 0.33$ $\mathrm{ml} / \mathrm{min}$ であったこと，松网 $5^{103}$ の機能不良時の流量が $0.02 \mathrm{ml} / \mathrm{min}$ であったことなどからみて， $T_{1 / 2} 5$ 分以内 (流量 $0.07 \mathrm{ml} / \mathrm{min}$ 以上) 起機能良好群すなわち rapid flow pattern 群としたのはほ䚾妥当でったと言光上う。異常 群である no flow pattern 群と delayed flow pattern 群と は，シャント機能の良否に関する成績にほとんど差がない ため, abnormal delayed flow pattern と一括して良いと思 われる。しかし，この abnormal delayed flow pattern の症 例す心てが，機能不良ではなかった，機能良好でもシャン 卜内葡液流量が緩徐な症例が存在寸るので，abnormal

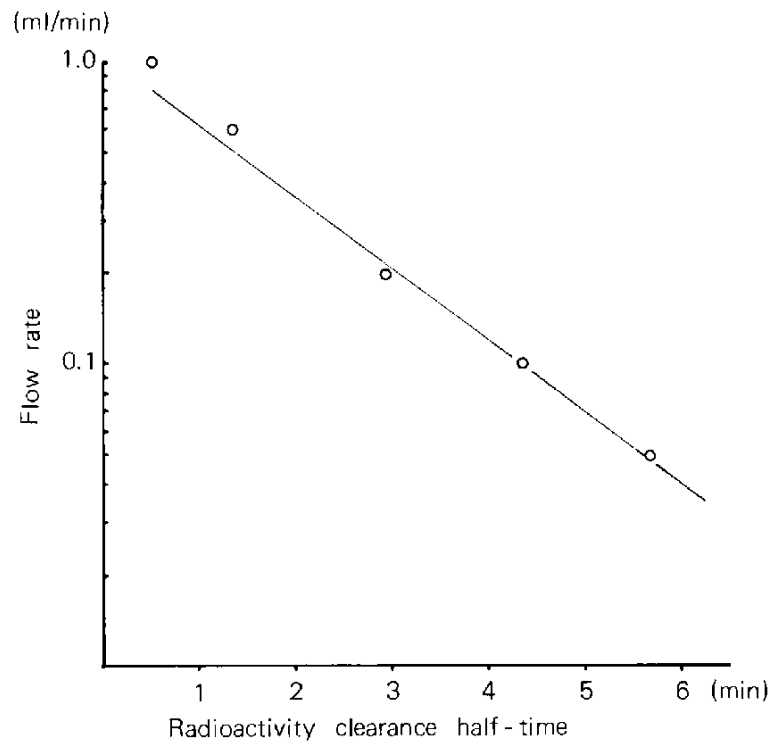

Fig 3 Flow rate and half-time of radioactivity clcarance $\mathrm{T}_{1 / 2}$ in the Pudenz flushing valve. dclayed flow pattern t示寸症例のシャント機能の良否鑑 別するために，French ら ${ }^{2)}$ ，Graham ら 位に体位変換しそこで再び flow study 老行い，flow の変化 をチェックす心゙きであると述ぶている。

\section{Shuntgraphyによる閉塞部位診断}

シャント機能が良好であるにもかかわらず shuntgramで 機能不良とされる大きな理由は，それらの症例では䯣液流 量が少ないため RI がバルブのパンピング後も十分拡散せ ずシャント閉塞があるものと䛊診されてしまらことであ る。したかって, abnormal delayed flow pattern 示与症例 のシャント機能の良否の決定 注 flow study と shuntgram のみからでは不十分であり，前述の体位変換による flow studyないしは後述の圧测定を併用せ小将ならない。 Shuntgram で中枢側機能不良とされた症例の䛊診率が高 かった理由のーつに，RIのバルブ注入部位の問題がある。 ナなわち，バルブを脳空侧に穿刺したつもりが末梢側に穿 刺されており，バルブのパンピング後も RI が脳室内に逆 流しないため，脳室側機能不良上誤診されたのである。 RI の腹腔側注入では脑室側機能不良を見落す可能性があると 言われている ため，我々は檤室側注大原則としてきた。 確かに， Mishler dual chamber flushing valve では脳窒側 穿刺は容易で女り，Hakim ஓ Rickham $の$ reservoir でも

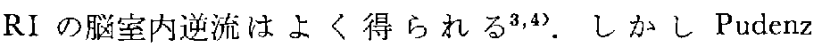
flushing valve Ł Mishler double lumen flushing valve で は，頭皮上からの外観は類似していてもバルブ内の構造が 著しく相違しているため，あら扎聥人されているバル ブの種類老知っていないと穿刺部位を謓りやすい。した

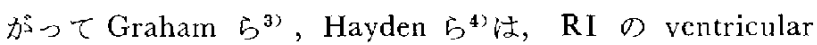
refux の有無のみからでは中枢側機能不良の診断は困難 で, 穿刺部位から髄液が排除できないときやバルブ内䯣液 压が異常に低くかつ波動在認めない上きに，中枢側機能不 良と診断すべきであるセ述べている。

\section{3. 低圧ないし正常压でシャント機能不良例}

バルブ穿刺ないし腰椎穿刺により髄液圧が $0 \sim 100 \mathrm{~mm}$ $\mathrm{H}_{2} \mathrm{O}$ と低值で，かつ機能不良であった症例を5例経験し た.これらはバルブ穿刺で $0 \mathrm{mmH}_{2} \mathrm{O}$ の脳室管閉塞の 1 例, $80 \sim 100 \mathrm{mmH}_{2} \mathrm{O}$ の木梢管閉塞 4 例であった，後者の 5 ち2 例は頭囲も大きく脳室拉大も著明であるが比較的症 状の乏しい小兄例，他の 2 例はクモ膜下出血後の成人水頭 症例であり，いずれも交通性水頻症であった。このように 低王の末梢側機能不良例は，良来あまり注目されていな

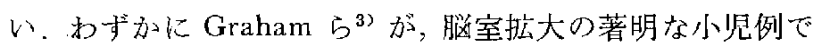
はシャント作動開始圧は高くてす䯣液の resting pressureは 低いすのがあると述心゙，また Hayden ら゙が, equivocalな 所見走示すもののなかにこのよらな症例が含まれているこ 


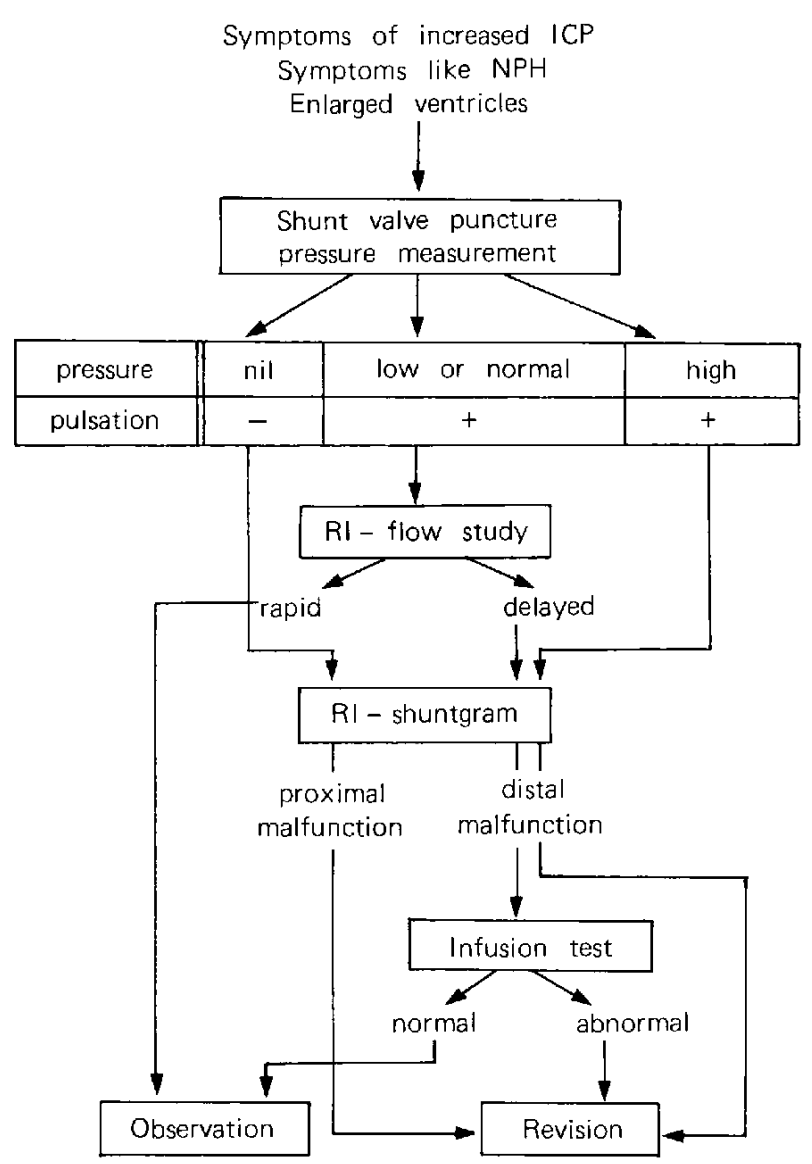

Fig. 4 Flow chart of shunt function tests. ICP indicates intracranial pressure; NPH, normal-pressure hydrocephalus; RI, radioisotope.

とを示唆しているのみである。これらの症例では，䯣液の resting pressure の測定のみではシャント機能の良否は判断 しか极る。松岡ら ${ }^{10}$ は，バルブ穿刺による加圧テストによ りバルブ開閉压を知ることができるとし，この方法を推奖 している。確かにある種のバルブでは，腷室側を穿刺する ことと RI 注入時に脳室側チューブを圧迫することが可能 なため，その場合は優れた方法であるが，脳室側チューブ を圧迫できないときやバルブの腹腔側を穿刺した際怯，バ ルブの開閉压を正しく示すとはがらない，そこで我及 は，腰椎穿刺下に扔ける infusion test を行った。本法は resting pressure に加えてシャントバルブの作動開始圧を知 ることができるので, flow study で abnormal delayed flow pattern 索し，かつバルブ内㵦液が波動を有し，低压な いし正常压を呈する症例のシャント機能の良否を鑑別する のに有用であった。

\section{4. シャント機能不良を疑った際の検查の進め方}

今まで述べたことから，我々のシャント機能テストに対
する考え方を flow chart として Fig. 4 に示した。バルブ 穿刺で葡液圧が低圧ないし正常圧のタのに RIによる

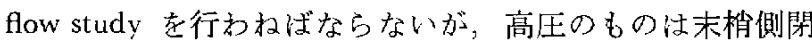
塞, 測定不能で波動のないものは中枢側閉塞であるから， 両者とも flow study の必要はなくただちに shuntgramで閉 塞部位在確認すれば良い。ここまでの所要時間は15分前後 である。ささらに，䯣液圧が低圧ないし正常圧でかつ abnormal delayed flow pattern 示すものは,バルブ作動開始圧 を知る目的で infusion test を行わ权ばならずここれ 30 〜40分を必要とする. したがって，準備時間を含めて，バ ルブ穿刺から終了までにほぼ60９0分を要する。

\section{V 結 語}

1. シャント機能検查は，RIによる flow study と shuntgraphy のみでは診断に際して不十分な症例があり， シャントバルブを穿刺して哊液圧の測定と波動の有無をチ エックする必要がある。

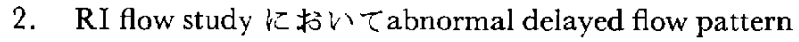
に属し，しかむ低圧ないし正常圧を示すもののなかにはシ ヤント機能良好群と不良群とがあり，この二群の鑑別には infusion test が有用である。

3. シャント機能テストの手順を示した.

\section{文献}

1) 姉川繁敬, 林 隆士, 石橋 彰, 本田英一郎, 大鳥勇紀, 倉本進賢，杉本武夫：乳幼児の頭蓋内測 定の臨床的意義 一正常児と頭蓋内疾患児の比較検討一，小児の膗神 6 ： $59-64,1981$

2) French BN, Swanson M: Radionuclide imaging shuntgraphy for evaluation of shunt patency. Surg Neurol 16: 173-182, 1981

3) Graham P, Howman-giler R, Johnston I, Besser M: Evaluation of CSF shunt patency by means of technetium99m-DTPA. $J$ Neurosurg 57: 262-266, 1982

4) Hayden PW, Rudd TG, Shurtleff DB: Combined pressure-radionuclide evaluation of suspected cerebrospinal fluid shunt malfunction: A seven-year clinical experience. Pediatrics 66: 679-684, 1980

5) Hill A, Volpe JJ: Normal pressure hydrocephalus in the newborn. Pediatrics 68: 623-629, 1981

6) 本田英一郎，林 隆士，正帛隆夫，姉川繁敬，合本進賢， 菊川武明：大泉門上加らの非観血的頭莣内圧測定装 置の 試作につWて. Neurol Med Chir (Tokyo) 22:640-648, 1982

7) Katzman R, Hussey F : A simple constant-infusion manometric test for measurement of CSF absorption. Neurology (Minneap) 20: 534-544, 1970

8）前田敏男，森 厚文，久田欣一，角家 先：脑室短絡系 路の核医学の閉塞部位診断 一実験的考察一。核医 13 ： 
$781-785, \quad 1976$

9）前田敏男, 森 厚文, 久田欣一, 角家 暁: 畄室短絡系 路の脊涟液流量測定法 ーファントーム奏験一。核医 14 : 297-301, 1977

10）松岡好美, 端 和夫：脑室腹腔吻合機能不全例に対する shunt function test $の$ 選抧. 脑神外科 8：43-48, 1980

11) 大矢昌紀, 津金隆一，伊藤正治，野尻 健，佐藤 修， 池井勝美：髄液短絡流量 定量的測定とShunt Systen 機能評佂．小览の脳神 $6: 255-263 ， 1981$

12) Rudd TG, Shurtleff DB, Losser JD, Nelp WB: Radionuclide assessment of cerebrospinal fluid shunt function in children. $J$ Nucl Med 14;683-686, 1973

13) Vidyasagar D, Raju TNK: A simple non invasive technique of measuring intracranial pressure in the newborn. Pediatrics 59: 957, 1977

14) Welch $\mathrm{K}$ : The intracranial pressure in infants. $J$ Neurosurg 52 : 693-699, 1980

〔別刷請求先： $\overline{\mathbf{T}} 305$ 茨城県新治郡桜村天王台，筑波大学檤 神释外科, 中田義隆] 